\title{
STRATIFIKASI PENGGUNAAN TAJUK OLEH YAKI (Macaca nigra) DI CAGAR ALAM TANGKOKO DUASUDARA SULAWESI UTARA
}

\author{
Sylvia Laatung
}

Fakultas Peternakan Universitas Sam Ratulangi Manado, 95115

\begin{abstract}
ABSTRAK
Habitat monyet hitam Sulawesi (Macaca nigra) di Kawasan Cagar Alam (CA) Tangkoko-Duasudara Sulawesi Utara masih menjadi fokus penelitian sejak tahun 1970an. Keberadaannya semakin terancam oleh perambahan habitat dan perburuan, yang menjadi ancaman utama. Pengamatan kondisi habitat (termasuk profil penggunaan stratum vegetasi) dan interaksi antara yaki dan penduduk sekitar kawasan telah dilakukan selama empat bulan. Metode yang digunakan untuk melakukan pengamatan habitat difokuskan pada penggunaan stratum vegetasi dan pohon tidur yaki, yang hasilnya digambarkan dalam bentuk diagram profil habitat. Dua bagian stratum yang paling banyak digunakan dalam beraktifitas adalah stratum A dan B. Persentase pemanfaatannya yaitu sebesar $65,21 \%$. Karakteristik pohon yang digunakan sebagai pohon tidur antara lain; dekat dengan sumber pakan dan minum, pohon yang tinggi dan besar, serta mempunyai percabangan yang banyak. Penyebaran populasi yaki tergantung pada ketersediaan sumber pakan dan berlindung di dalam hutan. Tanpa usaha untuk mengurangi perburuan dan perambahan hutan, populasi ini akan mengalami kepunahan.
\end{abstract}

Kata Kunci: Stratifikasi Penggunaan Tajuk, Macaca nigra, Kawasan Cagar alam

\section{ABSTRACT}

THE USE OF SHOOT STRATIFICATION OF YAKI (Macaca nigra) at DUASUDARA TANGKOKO NATURE RESERVE NORTH SULAWESI. The Sulawesi black macaques (Macaca nigra) habitat at the Tangkoko and Duasudara Nature
Reserves in North Sulawesi Indonesia has been the focus of periodic assessment since the late 1970s. Ongoing habitat loss and hunting remain the primary threats to the macaques in these adjacent reserves. Surveyed on habitat condition (including vegetation stratum utilization profile) and the interaction between yaki and local people around the nature reserve were conducted over a four-month period. Methods used diagram for habitat profile and interviewed for interaction between yaki and local people. They used stratum A and B frequently $(65.21 \%)$ in the forest and prefer big trees, with many branch to sleep. The spread of population depends on the availability of resources in the forest. Without increased efforts to reduce hunting pressure and habitat loss, the future of this population is in question.

Keywords: The use of shoot stratification, macaca nigra, nature reserve

\section{PENDAHULUAN}

Yaki (Macaca nigra) adalah salah satu spesies Macaca dari 7 spesies Macaca yang ada di Sulawesi (Fooden 1969 dalam Whitten et al. 1987). Diantara 3 spesies Macaca di Sulawesi bagian utara $(M$. nigra, $M$. nigrescens dan $M$.hecki), yaki merupakan jenis yang paling terancam keberadaannya. Hasil penelitian menunjukkan bahwa populasi maupun habitatnya semakin menurun dari tahun ke tahun. Kinnaird (1997) melaporkan bahwa 
akibat perburuan dan pengrusakan habitat saja, populasi yaki di Cagar Alam (CA) Tangkoko Duasudara yang merupakan salah satu tempat ditemukannya kelompok ini, telah mengalami penurunan $75 \%$ sejak tahun 1979.

CA Gunung Duasudara merupakan bagian dari kawasan CA Tangkoko Duasudara yang terletak di ujung tenggara semenanjung utara Kabupaten Minahasa. Kehadiran penduduk desa sekitar kawasan CA Gunung Duasudara menimbulkan beberapa permasalahan yang secara langsung atau tidak langsung mengancam kehidupan yaki.

Permasalahan klasik yang dialami oleh hampir setiap negara terhadap keberadaan satwaliar termasuk satwa primata adalah masalah perburuan dan perambahan hutan. Masalah tersebut juga terjadi di CA Gunung Duasudara. Ketergantungan masyarakat terhadap kawasan hutan dan hasil hutan yang sangat tinggi, memicu masyarakat untuk melakukan kegiatan perambahan hutan, penebangan liar, perburuan dan perdagangan liar. Belum lagi masalah lain yang tidak bisa dikendalikan seperti bencana alam (kebakaran), yang kerap terjadi di sekitar kawasan. Faktor lain yang ikut menambah semua tekanan di atas yaitu lemahnya pengelolaan kawasan lindung oleh pemerintah maupun pihat terkait.
Dalam rangka pembinaan dan pengelolaan kawasan guna menyelamatkan yaki diperlukan data dasar. Adapun data dan informasi terbaru mengenai habitat yaki di CA Gunung Duasudara yang sampai saat ini masih terbatas. Hal-hal inilah yang menjadi dasar mengapa penelitian ini perlu dilakukan.

\section{MATERI DAN METODE PENELITIAN}

\section{Waktu dan Tempat}

Penelitian ini telah dilaksanakan di

CA Gunung Duasudara. Penelitian berlangsung kurang lebih empat bulan.

\section{Alat dan Bahan}

Alat yang digunakan adalah: kompas, binokuler, pita transek, GPS (Global Positioning System) Garmin, kamera, meteran $(50 \mathrm{~m})$, dbh (diameter at breast height) $\mathrm{m}$ dan alat tulis menulis. Bahan antara lain: peta lokasi penelitian (skala 1:50.000), borang, koran dan alkohol.

\section{Metode Penelitian}

Studi pendahuluan di lapangan dilakukan beberapa minggu sebelum penelitian dilaksanakan. Pengamatan habitat difokuskan pada pemanfaatan strata atau tajuk pohon oleh yaki dalam melakukan aktivitas, serta pengamatan pohon tidur (sleeping trees). 
Pengamatan pemanfaatan strata ini dilakukan dengan mencatat selang ketinggian di atas pohon, yang digunakan oleh yaki serta aktivitas yang dilakukan ketika terlihat. Pemanfaatan stratum oleh yaki dibagi menjadi 5 kategori yaitu:

a) stratum A dengan ketinggian diatas 20 $\mathrm{m}$, merupakan lapisan teratas yang mempunyai batang tinggi, tegak lurus dan bertajuk diskontinu;

b) stratum $\mathrm{B}$ dengan ketinggian antara 10-20 m, umumnya bertajuk kontinu dan batang pohon banyak bercabang;

c) stratum $\mathrm{C}$ dengan ketinggian antara 5$10 \mathrm{~m}$, tajuknya kontinu, terdiri dari pohon-pohon yang kecil, rendah dan banyak cabang;

d) stratum D adalah lapisan perdu dan semak, tingginya $0-5 \mathrm{~m}$;

e) stratum E merupakan lantai hutan dan lapisan penutup tanah.

Pengamatan pemanfaatan pohon tidur/makan yang digunakan yaki, dilakukan dengan membuat masingmasing satu plot vegetasi, dengan ukuran 20x50 m. Plot dibuat pada daerah tempat yaki tidur/makan, dengan mengidentifikasi semua pohon dalam petak contoh yang mempunyai $\mathrm{dbh} \geq 20 \mathrm{~cm}$. Plot ini dibuat di tempat yang berbeda, tetapi masih dalam kawasan CA Gunung Duasudara, yaitu daerah Pinangunian (plot A), daerah
Duasudara (plot B) dan daerah Temboan (plot C).

Data yang dicatat yaitu jenis, tinggi dan diameter pohon, tinggi dan lebar tajuk, serta posisi pohon dalam plot contoh. Pohon yang tidak diketahui jenisnya, kemudian dibuat herbarium dan diidentifikasi di laboratorium Herbarium Bogoriense Bogor. Data yang diperoleh kemudian digambarkan dengan menggunakan Program Corel Draw 12, sehingga diperoleh profil pohon tidur/makan yang digunakan oleh yaki.

\section{HASIL DAN PEMBAHASAN}

\section{Kondisi Habitat CA Gunung Duasudara}

Sesuai dengan hasil pengamatan langsung di lokasi penelitian, secara umum keadaan hutan CA Gunung Duasudara cukup memprihatinkan. Berbagai praktek perusakan hutan, masih sering terjadi di cagar alam ini. Perladangan berpindah, yang telah merambah kawasan cagar alam, terus dilakukan oleh penduduk yang berada di sekitar kawasan, dengan menanam tanaman perkebunan.

Salah satu contoh perambahan hutan untuk dijadikan areal perkebunan di daerah perbatasan antara Desa Pinangunian dan CA Gunung DuasudaraMenurut informasi yang 
diperoleh dari pihak Lembaga Swadaya Masyarakat (LSM), yang melakukan patroli di kawasan CA TangkokoBatuangus Duasudara, beberapa tahun yang lalu daerah tersebut masih baik dan layak sebagai habitat alami yaki. Perambahan hutan terjadi juga di daerah Temboan yang letaknya hampir berbatasan dengan CA Tangkoko-Batuangus. Daerah ini berada di sebelah timur laut Desa Duasudara, tepat disisi jalan utama yang menjadi penghubung antara desa-desa di sebelah utara dan Kota Bitung. Letak daerah yang berada di sisi jalan ini, mempermudah akses masyarakat untuk membuka lahan. Dahulu daerah ini masih hutan, bahkan sering terlihat beberapa kelompok yaki bermain atau mencari makan di tempat tersebut. Namun saat ini tempat tersebut telah berubah menjadi kebun oleh penduduk yang tinggal di sekitarnya. Beberapa penduduk memanfaatkan kawasan sebagai tempat untuk menggembalakan ternak.

\section{Pemanfaatan Stratum}

Persentase pemanfaatan stratum oleh yaki dapat dilihat pada Tabel 1 .
Data yang diperoleh menunjukkan bahwa yaki memanfaatkan semua bagian stratum. Stratum A dan B (tinggi lebih dari $10 \mathrm{~m})$ dengan persentase pemanfaatan $65,21 \%$, adalah dua bagian stratum yang paling banyak digunakan dalam beraktivitas. Stratum ini merupakan kumpulan pohon yang membentuk suatu kanopi tertutup dengan tajuk yang bersentuhan. Aktivitas yang dilakukan pada saat teramati adalah makan dan bergerak/berjalan.

Yaki menyukai bagian tepi tajuk pada kedua stratum ini karena bagian tumbuhan yang dimakan seperti buah, bunga dan pucuk daun muda berada pada tepi tajuk suatu individu pohon. Kesukaan yaki untuk bergerak pada kedua stratum ini terutama untuk berpindah dari satu pohon ke pohon lain, karena keadaan tajuk yang kontinu (saling bersentuhan) sehingga yaki dapat bergerak cepat tanpa harus berpindah stratum. Yaki juga memanfaatkan bagian stratum ini untuk bersembunyi, karena pada bagian ini terdapat percabangan pohon yang berukuran besar, terutama pada stratum B.

\section{Tabel 1. Persentase pemanfaatan stratum oleh yaki}

\begin{tabular}{cc}
\hline Stratum & Persentase \\
\hline A & 30,43 \\
B & 34,78 \\
C & 13,04 \\
D & 8,71 \\
E & 13,04 \\
\hline
\end{tabular}


Lantai hutan (stratum E) digunakan oleh yaki untuk beristirahat atau duduk. Ketika beristirahat atau tidur, yaki lebih memilih stratum A dan B dengan ketinggian lebih dari $10 \mathrm{~m}$. Stratum D paling sedikit digunakan untuk beraktivitas. Biasanya digunakan oleh yaki untuk berpindah stratum dalam satu pohon yang sama.. Alikodra (2002) menyatakan bahwa suatu masyarakat satwaliar dapat dibedakan menurut perbedaan lapisan hutan. Setiap stratum mempunyai kemampuan untuk mendukung kehidupan jenis-jenis satwaliar tertentu.

\section{Karakteristik Lokasi Pohon Tidur Yaki}

Yaki cenderung memilih pohon yang berukuran besar, dan bercabang banyak, sehingga memungkinkan bagi seluruh anggotanya untuk tidur. Pohonpohon besar yang letaknya berdekatan dalam satu tempat lebih disukai. Percabangan yang banyak, dengan daun yang lebat, juga membantu yaki untuk menghindar dari gangguan predator ketika beristirahat.

Profil pohon tidur di plot A (Gambar 1), terdapat pohon-pohon yang berukuran besar diameter antara 20,2$102,4 \mathrm{~cm}$, dan tinggi pohon antara 13-26 m. Beberapa jenis pohon yang dijadikan tempat untuk tidur yaitu Macaranga celebica Koord., Eugenia sp. (jambu), Ficus celebicum dan Syzygium (pakoba).
Keempat pohon ini memiliki percabangan yang banyak, dengan tinggi tajuk antara 9$15 \mathrm{~m}$.

Sama halnya dengan plot B (Gambar 2), pohon-pohon pada plot ini memiliki ukuran yang besar, namun jumlahnya lebih banyak dari plot $\mathrm{A}$. Beberapa jenis pohon yang ada pada plot A juga ditemukan pada plot ini seperti Eugenia sp.(jambu) dan Syzygium (pakoba). Pada plot B, jenis pohon lebih bervariasi jenisnya, dengan rata-rata tinggi pohon $16,58 \mathrm{~m}$, dan berdiameter $20,3-63,7$ cm. Pohon-pohon yang digunakan oleh yaki untuk tidur yaitu Talauma candoli, Trema orientalis (ruku) dan Cananga odorata (kenanga).

Profil pohon tidur yang terletak pada plot C (Gambar 2) berjarak kurang lebih $40 \mathrm{~m}$ dari sumber air. Letak pohon tidur yang dekat dengan air, bisa menjadi salah satu alasan yang membuat yaki memilih lokasi tersebut sebagai tempat beristirahat. Beberapa jenis pohon yang berukuran besar $(\mathrm{dbh}>30 \mathrm{~cm})$ yang terdapat di lokasi tersebut yaitu Arenga pinnata (seho), Myristica fatua, Cananga odorata (kenanga), Dendrocnide microstigma (sosoro), Gleditschia rolfei, Syzygium sp.(pakoba) dan Maranthes corymbosa. Rata-rata pohon ini memiliki tinggi lebih dari $20 \mathrm{~m}$, dengan lebar tajuk 6-15 m. 
Pada kesempatan yang lain di lokasi ini juga, yaki terlihat sedang mencari makan. Beberapa jenis pohon yang menjadi sumber pakan pada plot ini dan ditemukan juga pada lokasi sebelumnya yaitu Cananga odorata (kenanga), Syzygium sp. (pakoba), Arenga pinnata (seho), Eugenia sp. (jambu) dan beberapa jenis Ficus (beringin). Ficus termasuk jenis pakan yang melimpah di CA Tangkoko Duasudara. Selain berbuahnya tidak mengenal musim, Ficus kaya akan kandungan nutrisi terutama Calsium dan Magnesium (Kinnaird et al.1999).

Menurut Alikodra (2002), beberapa jenis pohon (misalnya Ficus sp.) yang tajuknya berbentuk payung, sangat disukai oleh primata dan burung sebagai tempat berlindung, beristirahat dan sekaligus untuk mencari makan. Dikatakan pula bahwa struktur vegetasi suatu pohon sangat menentukan peranannya sebagai pelindung, terutama ditentukan oleh tajuk dan percabangannya. Lokasi pohon tidur yang digunakan biasanya lebih dari satu/berpindah-pindah. Hal ini bisa disebabkan oleh luasnya daerah jelajah ataupun ketersediaan pakan di hutan. Profil pohon tidur hasil pengamatan yang digunakan oleh yaki pada setiap plot dapat dilihat pada Gambar 1, 2 dan 3. 


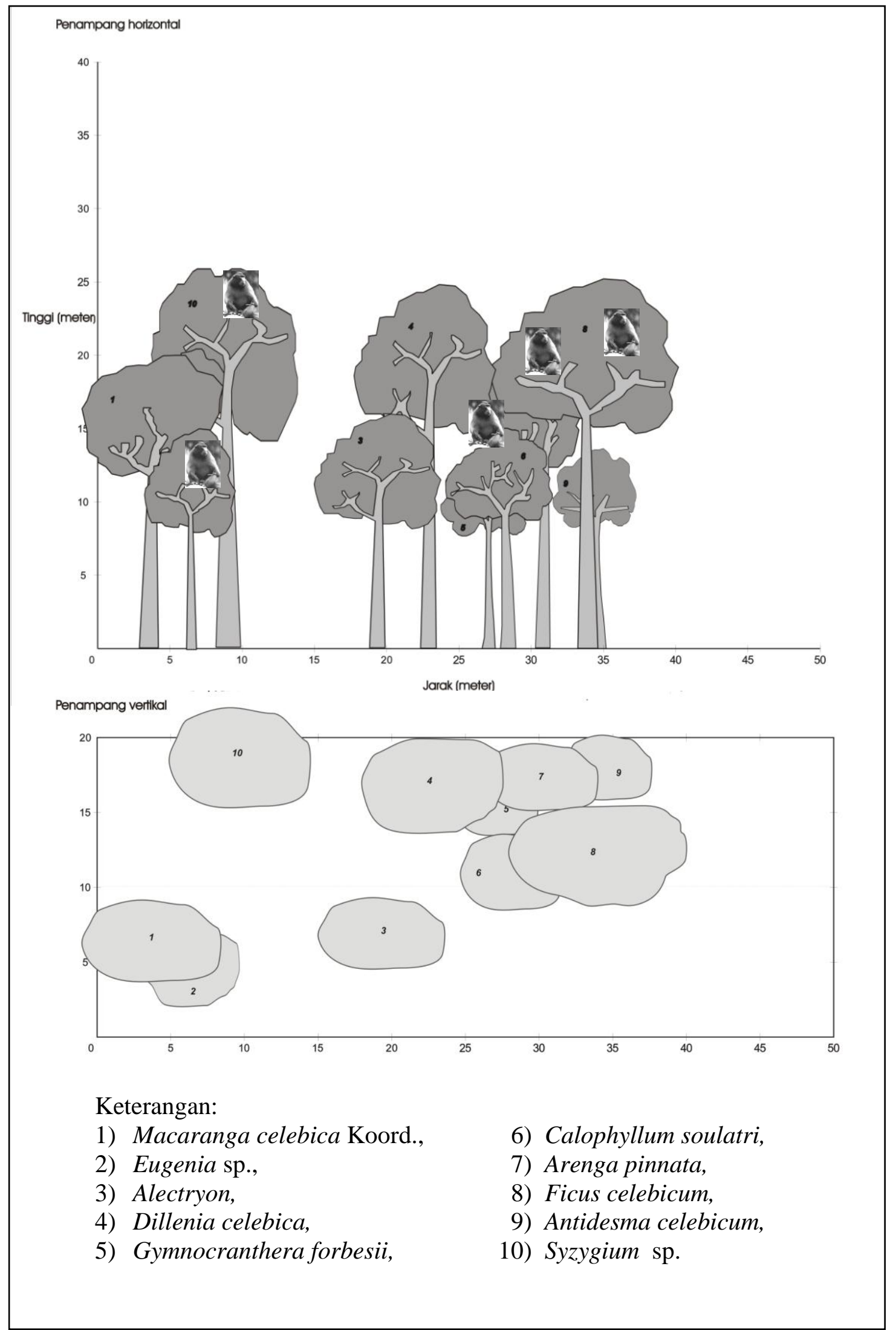

Gambar 1 Profil pohon tidur di plot A (daerah Pinangunian) 


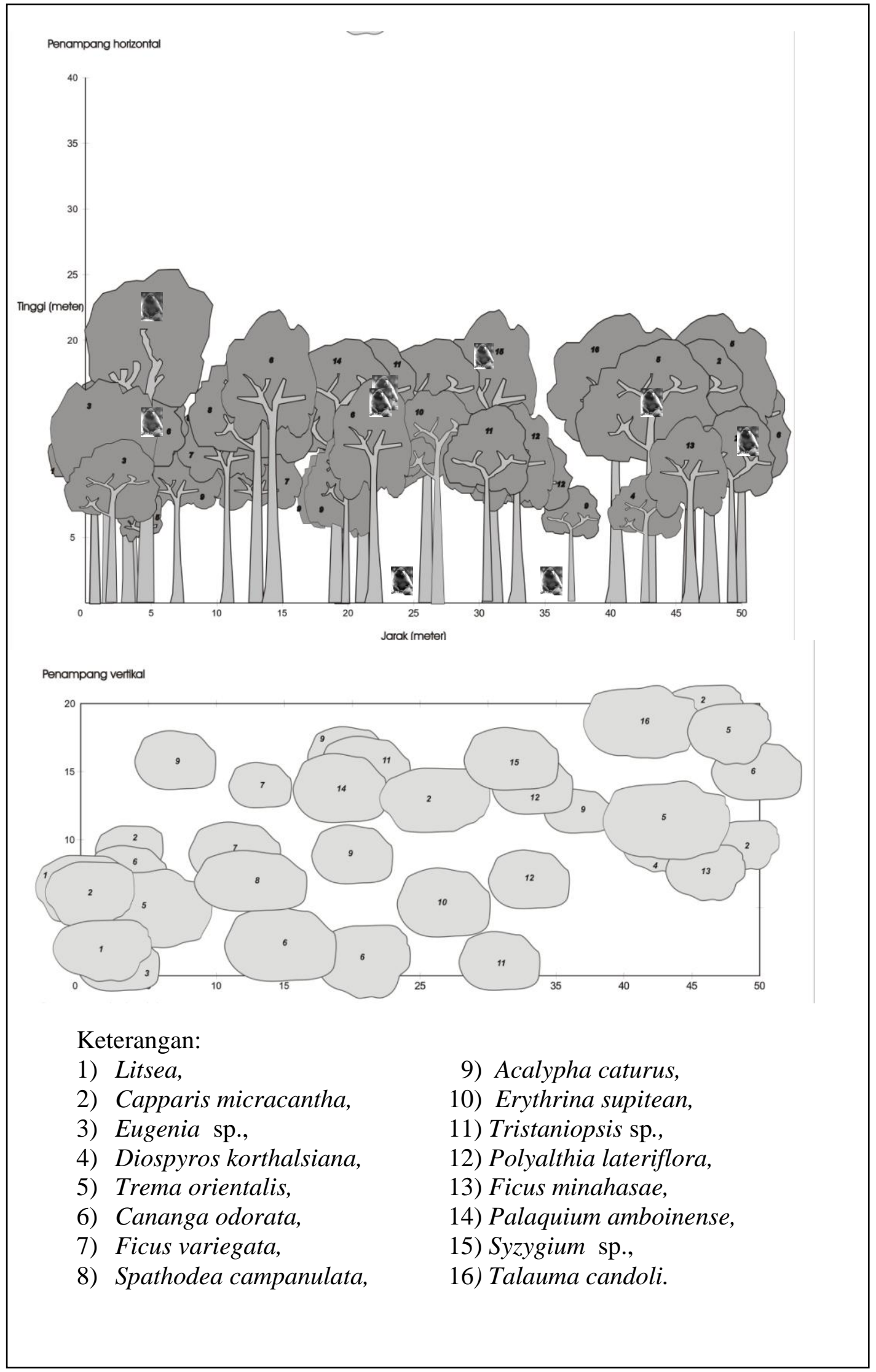

Gambar 2 Profil pohon tidur di plot B (daerah Duasudara). 

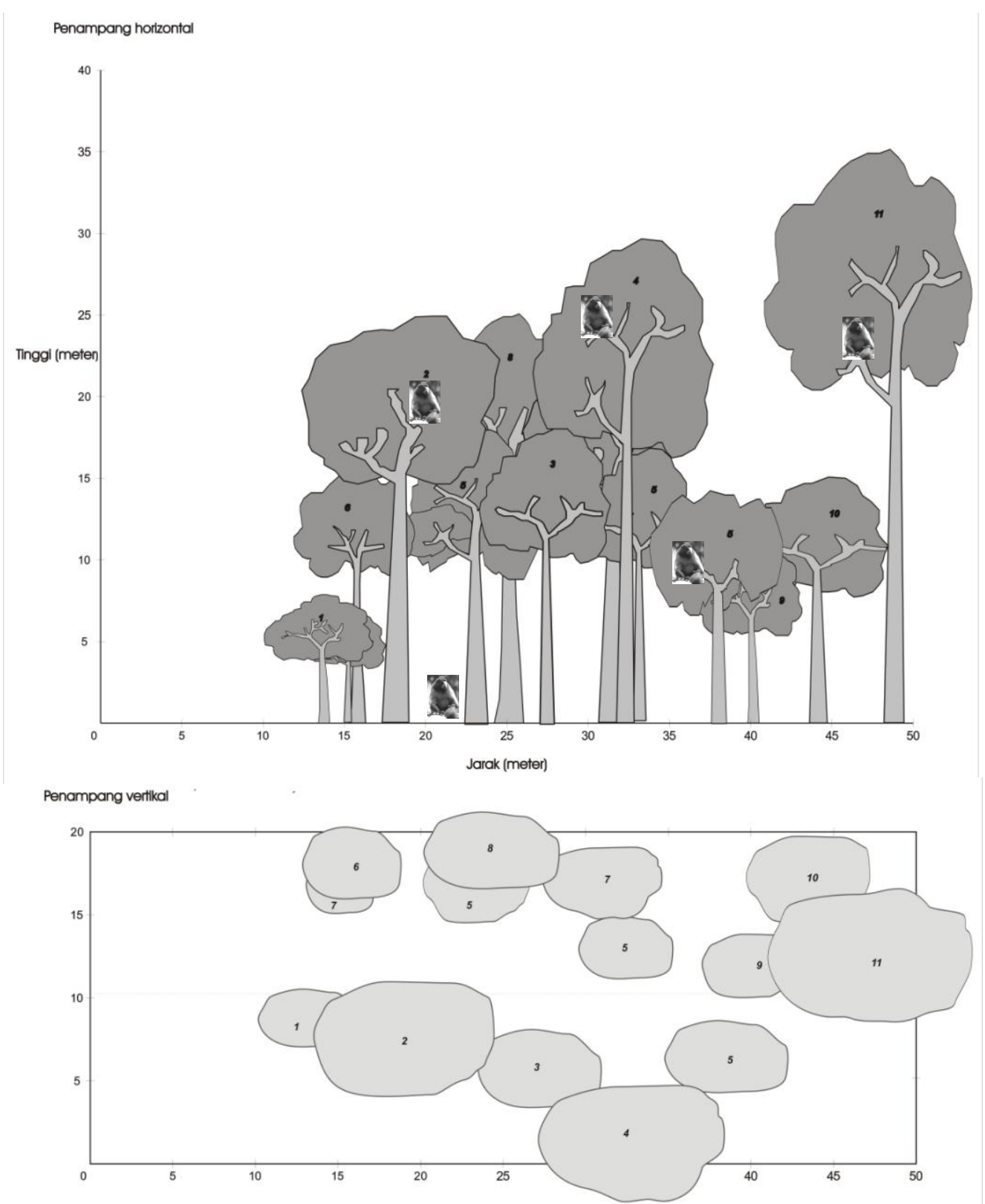

Keterangan:
1) Arenga pinnata,
2) Myristica fatua,
3) Dendrocnide microstigma,
4) Cananga odorata,
5) Lithocarpus celebicus,
6) Palaquium amboinense,
7) Livistona rotundifolia,
8) Gleditschia rolfei,
9) Syzygium sp.,
10) Polyalthia glauca,
11) Maranthes corymbosa.

Gambar 3 Profil pohon tidur di plot C (daerah Temboan). 
Peta lokasi penelitian dan sebaran lokasi pohon tidur dan pohon pakan yaki.

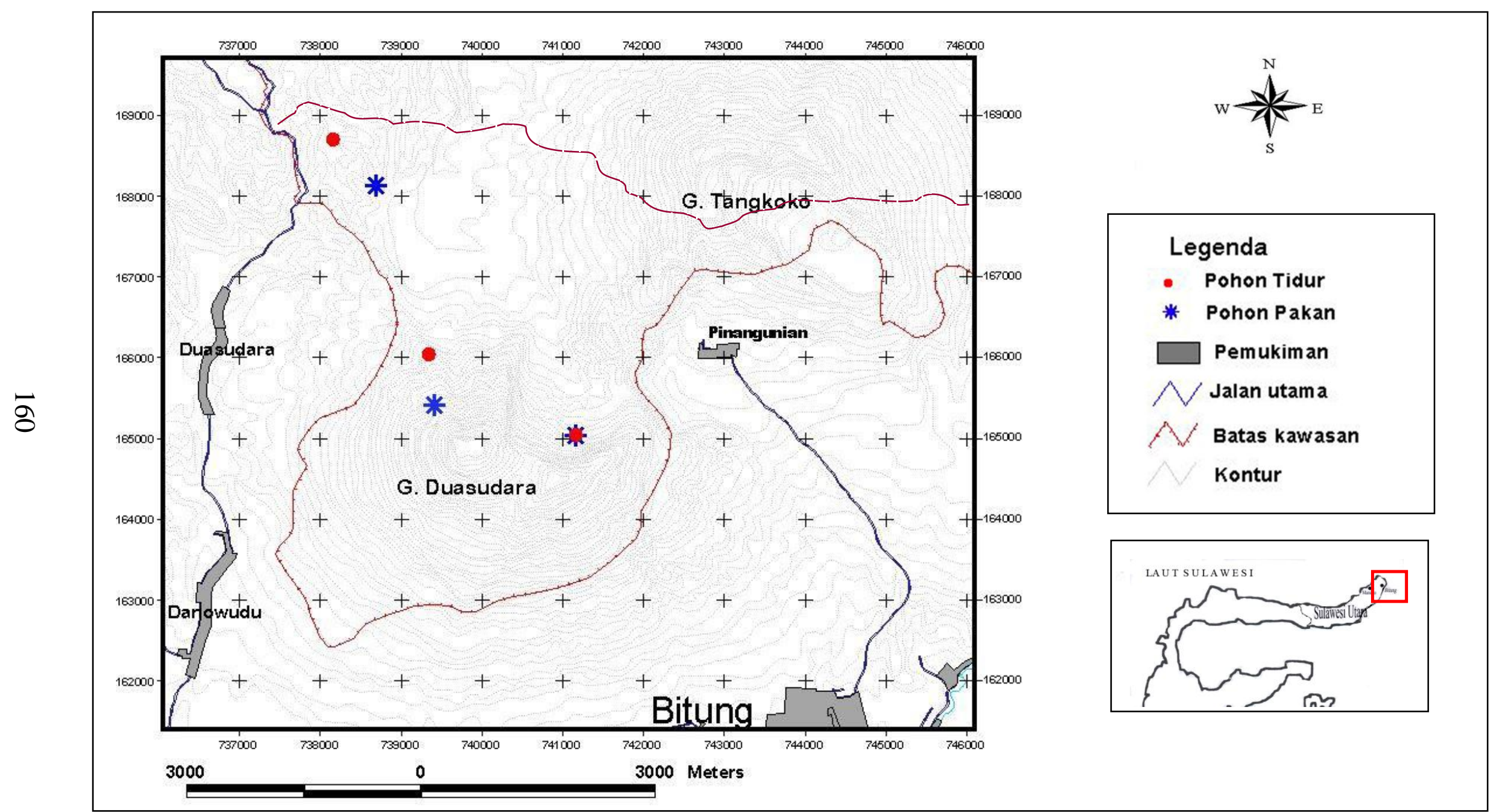


Nama-nama tumbuhan yang ditemui di lokasi penelitian

\begin{tabular}{|c|c|c|c|c|}
\hline No. & Famili & Nama Latin & Nama Lokal & Ket. \\
\hline 1. & Actinidiaceae & Saurauia tristyla & Hegungpung & \\
\hline 2. & Actinidiaceae & Saurauia euryolepis & & \\
\hline 3. & Anacardiaceae & Dracontomelon mangiferum & Leu & $\sqrt{ }$ \\
\hline 4. & Anacardiaceae & Dracontomelon dao & & $\sqrt{ }$ \\
\hline 5. & Anacardiaceae & Parishia pilippensis & Kayu susu & \\
\hline 6. & Anacardiaceae & Spondias dulcis & & \\
\hline 7. & Annonaceae & Cananga odorata & Kenanga & $\sqrt{ }$ \\
\hline 8. & Annonaceae & Polyalthia lateriflora & Kalakapuk daun besar & \\
\hline 9. & Annonaceae & Polyalthia glauca & Salakapuk & \\
\hline 10. & Apocynaceae & Alstonia sumatrana & Kbayu telur & \\
\hline 11. & Apocynaceae & Alstonia ranvolfia(scholaris) & & $\sqrt{ }$ \\
\hline 12. & Araliaceae & Polyscias nodosa & Titolang & \\
\hline 13. & Bignoniaceae & Spathodea campanulata & Kayu bunga/kayu perahu & \\
\hline 14. & Burceraceae & Canarium vrieseanum & Kenari sedang & \\
\hline 15. & Burceraceae & Canarium asperum & Damar babi & \\
\hline 16. & Burceraceae & Canarium hirsutum & & $\sqrt{ }$ \\
\hline 17 & Casuarinaceae & Euonymus javanicus & & \\
\hline 18 & Casuarinaceae & Lophopetalum javanicum & & \\
\hline 19. & Capparidaceae & Capparis micracantha & Kuning keras & \\
\hline 20. & Chrysobalanaceae & Maranthes corymbosa & & \\
\hline 21. & Combretaceae & Terminalia celebica & Nusu hutan & \\
\hline 22. & Cyatheaceae & Cyathea sp. & Pakis & \\
\hline 23. & Datiscaceae & Tetrameles nudiflora & Bolangitan & \\
\hline 24. & Dilleniaceae & Dillenia ochreata & Kol & \\
\hline 25. & Dilleniaceae & Dilennia glauca & & \\
\hline 26. & Dilleniaceae & Dillenia celebica & Rerer & \\
\hline 27. & Ebenaceae & Diospyros korthalsiana & Kayu hitam & \\
\hline 28. & Euphorbiaceae & Acalypha caturus & Kayu biru & \\
\hline 29. & Euphorbiaceae & Antidesma celebicum & & \\
\hline 30. & Euphorbiaceae & Antidesma tetrandum & & \\
\hline 31. & Euphorbiaceae & Aporusa grandispulata & & \\
\hline 32. & Euphorbiaceae & Baccaurea javanica & & \\
\hline 33. & Euphorbiaceae & Drypetes neglecta & & $\sqrt{ }$ \\
\hline 33. & Euphorbiaceae & Macaranga celebica Koord. & & \\
\hline 34. & Euphorbiaceae & Macaranga mappa & Binunga daun besar & $\sqrt{ }$ \\
\hline 35. & Euphorbiaceae & Mallotus columnaris & & \\
\hline 36. & Euphorbiaceae & Mallotus ricinoides & & \\
\hline 37. & Fogaceae & Lithocarpus celebicus & & \\
\hline 38. & Flacourtiacea & Casearia grawiaefolia & & \\
\hline 39. & Flacourtiacea & Homalium celebicum & Krikis tanjung & \\
\hline 40. & Gnetaceae & Gnetum gnemon & & \\
\hline 41. & Guttiferae & Calophyllum soulatri & Kapuraca & \\
\hline 42. & Guttiferae & Garcinia parvifolia & Manggis akar kaki & \\
\hline 43. & Guttiferae & Garcinia tetrandra & Manggis hutan & \\
\hline 44. & Lauraceae & Cryptocarya bicolor & Pemuli & \\
\hline 45. & Lauraceae & Cryptocarya celebica & & \\
\hline 46. & Lauraceae & Litsea & & \\
\hline 47. & Lechythidaceae & Planchonia valida & Ipil & \\
\hline 48. & Leeaceae & Leea aculeate & Mamaling/akar kaki & \\
\hline 49. & Leeaceae & Leea indica & & \\
\hline 50 & Leguminosae & Erythrina supiteana & & \\
\hline 51. & Magnoliaceae & Talauma candoli & & \\
\hline 52. & Malastomataceae & Astronia stapfii & & \\
\hline \multirow[t]{2}{*}{53.} & Meliaceae & Aglaia sp. & & \\
\hline & Nama Famili & Nama Latin & Nama Lokal & Ket. \\
\hline 54. & Meliaceae & Chisocheton Kingii & Kayu rangkong & \\
\hline 55. & Meliaceae & Dysoxylum densiflorum & & \\
\hline
\end{tabular}




\begin{tabular}{|c|c|c|c|c|}
\hline 56. & Moraceae & Ficus sp. & Beringin & $\sqrt{ }$ \\
\hline 57. & Moraceae & Ficus pubinervis & Beringin & $\sqrt{ }$ \\
\hline 58. & Moraceae & Ficus caulocarpa & & $\sqrt{ }$ \\
\hline 59. & Moraceae & Ficus benjamina & Kedondong hutan & $\sqrt{ }$ \\
\hline 60. & Moraceae & Ficus celebicum & & \\
\hline 61. & Moraceae & Ficus minahasae & & \\
\hline 62. & Moraceae & Ficus variegate & Coro & \\
\hline 63. & Moraceae & Ficus virens & & $\sqrt{ }$ \\
\hline 64. & Moraceae & Ficus septica & & \\
\hline 65. & Moraceae & Arthocarpus dadha & & \\
\hline 66. & Myristicaceae & Gymnocranthera forbesii & Pala hitam & \\
\hline 67. & Myristicaceae & Horsfieldia brachiata & Pala kecil & \\
\hline 68. & Myristicaceae & Knema sp. & Pala & \\
\hline 69. & Myristicaceae & Knema latericia & Pala kecil & \\
\hline 70. & Myristicaceae & Myristica fatua & & \\
\hline 71. & Myrtaceae & Eugenia sp. & Jambu & $\sqrt{ }$ \\
\hline 72. & Myrtaceae & Syzygium sp. & Pakoba & $\sqrt{ }$ \\
\hline 73. & Myrtaceae & Tristaniopsis sp. & & \\
\hline 74. & Myrtaceae & Arenga pinnata & Seho & $\sqrt{ }$ \\
\hline 75. & Myrtaceae & Caryota mitis & & \\
\hline 76. & Myrtaceae & Livistona rotundifolia & & \\
\hline 77. & Piperaceae & Piper aduncum & Kayu sirih & $\sqrt{ }$ \\
\hline 78. & Rhamnaceae & Zizyphus angustifolius & Lawang tikus & \\
\hline 79. & Rubiaceae & Anthocephalus sp. & & \\
\hline 80. & Rubiaceae & Rothmannia sp. & & \\
\hline 81. & Rutaceae & Euodia minahasae & Singio & \\
\hline 82. & Sabiaceae & Meliosma cf.Ferruginea Blume & & \\
\hline 83. & Sabiaceae & Meliosma nitida Blume & & \\
\hline 84. & Sapindaceae & Harpulia cupaniodes & Kayu roda & \\
\hline 85. & Sapotaceae & Palaquium amboinense & Nantu & $\sqrt{ }$ \\
\hline 86. & Sterculiaceae & Melochia umbellate & & \\
\hline 87. & Sterculiaceae & Pterospermum celebicum & Wolo & \\
\hline 88. & Sterculiaceae & Pterocymbium javanicum & Kayu wol & $\sqrt{ }$ \\
\hline 89. & Sterculiaceae & Sterculia insularis & Momas & \\
\hline 90. & Tiliaceae & Grewia sp. & & \\
\hline 91. & Ulmaceae & Trema orientalis & Ruku & \\
\hline 92. & Urticaceae & Dendrocnide microstigma & Sosoro & \\
\hline 93. & Urticaceae & Leucosyke capitellata & Kepala birang & \\
\hline 94. & Urticaceae & Villebrunea rubescens & Kepala birang/burara & \\
\hline 95 & & Alectryon & Biji terong & \\
\hline 96. & & Gleditschia rolfei & & \\
\hline 97. & & Lantana camara & & \\
\hline 98. & & Imperata cylindrica & & \\
\hline 99. & & Mimosa pudica & & \\
\hline
\end{tabular}

Keterangan:

$\sqrt{ }=$ sumber pakan yaki 


\section{KESIMPULAN}

1. Yaki memanfaatkan semua bagian strata dalam melakukan aktivitas. Stratum A dan B (tinggi lebih dari 10 m) dengan persentase pemanfaatan $65,21 \%$, adalah dua bagian stratum yang paling banyak digunakan dalam beraktivitas. Pemilihan lokasi pohon tidur terutama di daerah yang tersedia sumber pakan dan minum, dengan karakteristik pohon yang tinggi, besar dan mempunyai percabangan yang banyak. Pohon yang membentuk suatu kanopi tertutup dengan tajuk yang bersentuhan lebih disukai. Pohonpohon yang digunakan sebagai pohon tidur antara lain Ficus spp., Eugenia, Zyzygium, dan Cananga odorata, Macaranga celebica Koord., Talauma candoli dan Trema orientalis.

2. Keadaan habitat di CA Gunung Duasudara saat ini secara umum semakin memburuk. Luas kawasan semakin mengecil akibat perambahan hutan. Sebagai respon terhadap perambahan hutan dan perburuan liar, yaki cenderung membentuk kelompokkelompok dengan jumlah anggota yang kecil dan tingkah laku yaki pun menjadi semakin liar. Selain itu penyebarannya semakin jauh masuk ke dalam hutan. Pohon-pohon yang besar dan memiliki tajuk yang rapat pada habitat tersebut, digunakan oleh yaki untuk mencari makan, beristirahat atau berlindung terutama dari ancaman pemburu.

\section{DAFTAR PUSTAKA}

Alikodra, H.S. 2002. Pengelolaan Satwaliar. Jilid I. Bogor: Yayasan Penerbit Fakultas Kehutanan IPB.

Kinnaird, M.F. 1997. Sulawesi Utara. Sebuah Panduan Sejarah Alam. Jakarta: Percetakan Redikencana.

Kinnaird, M.F., T.G. O'Brien, S. Suryadi. 1999. The Importance of Figs to Sulawesi's Imperiled Wildlife. Tropical Biodiversity 6(1\&2):5-18

Supriatna, J. dan J.W. Hendras. 2000. Primata Indonesia. Panduan Lapangan. Jakarta: Yayasan Obor Indonesia.

Whitten, A.J., Mustafa, dan G.S. Henderson. 1987. Ekologi Sulawesi. Gadjah Mada University Press, Yogyakarta 